\title{
Potential Pitfalls of SDH Immunohistochemical Detection in Paragangliomas and Phaeochromocytomas Harbouring Germline SDHx Gene Mutation
}

\author{
RAFFAELLA SANTI ${ }^{1}$, ELENA RAPIZZI ${ }^{2}$, LETIZIA CANU $^{2}$, TONINO ERCOLINO ${ }^{2}$, GIANNA BARONI ${ }^{1}$, \\ ROSSELLA FUCCI ${ }^{2}$, GIUSEPPE COSTA ${ }^{2}$, MASSIMO MANNELLI ${ }^{2}$ and GABRIELLA NESI ${ }^{1}$ \\ ${ }^{1}$ Division of Pathological Anatomy, and ${ }^{2}$ Department of Clinical Pathophysiology, \\ University of Florence, Florence, Italy
}

\begin{abstract}
Background/Aim: Germline mutations in any of the succinate dehydrogenase (SDH) genes result in destabilization of the SDH protein complex and loss of $S D H B$ expression at immunohistochemistry. SDHA is lost together with SDHB in SDHA-mutated tumours, but its expression is retained in tumours with other SDH mutations. We investigated whether SDHA/SDHB immunohistochemistry is able to identify $S D H$-related tumours in a retrospective case series of phaeochromocytomas (PCCs) and paragangliomas (PGLs). Materials and Methods: SDHA and $S D H B$ immunostaining was performed in 13 SDH genemutated tumours (SDHB: $n=3 ;$ SDHC: $n=1 ; S D H D: n=9$ ) and 16 wild-type tumours. Protein expression by western blot analysis and enzymatic activity were also assessed. Results: Tumours harbouring SDH gene mutations demonstrated a significant reduction in enzymatic activity and protein expression when compared to wild-type tumours. SDHB immunostaining detected $76.9 \%$ of SDH mutated PCCs/PGLs (3/3 SDHB-mutated samples; $1 / 1$ SDHCmutated sample; 6/9 SDHD-mutated samples). In three SDHD-related tumours with the same mutation (p.Pro81Leu), positive ( $n=2$ ) or weakly diffuse ( $n=1) S D H B$ staining was observed. All wild-type PCCs/PGLs exhibited $S D H B$ immunoreactivity, while immunostaining for SDHA was positive in $93.8 \%$ cases and weakly diffuse in one (6.2\%). SDHA protein expression was preserved in all tumours with mutations. Conclusion: SDHA and SDHB immunohistochemistry should be interpreted with caution, due to possible false-positive or false-negative results, and
\end{abstract}

Correspondence to: Professor Gabriella Nesi, Division of Pathological Anatomy, Department of Surgery and Translational Medicine, University of Florence, Largo Brambilla 3, 50134 Florence, Italy. Tel: +39 0554478114, e-mail: gabriella.nesi@unifi.it

Key Words: Phaeochromocytoma, paraganglioma, immunohistochemistry, succinate dehydrogenase, SDHB, SHDA. ideally in the setting of quality assurance provided by molecular testing. In SDHD mutation, weak non-specific cytoplasmic staining occurs commonly, and this pattern of staining can be difficult to interpret with certainty.

Succinate dehydrogenase (SDH), also referred to as mitochondrial complex II, plays an important role in cellular metabolism. SDH is involved in both the Krebs cycle, catalyzing the oxidation of succinate to fumarate, and the respiratory chain where it transfers electrons to coenzyme $\mathrm{Q}$ (1). It is encoded by four separate genes ( $D D H A, S D H B$, $S D H C, S D H D$, collectively referred to here as $S D H x$ ), any of which may be mutated to cause hereditary phaeochromocytomas (PCCs) and paragangliomas (PGLs) (2).

The link between SDH and neuroendocrine tumours was discovered in 2000, when germline mutations in the SDHD gene were described in patients with familial PGL (3). These mutations were later recognised in patients with apparently sporadic PCC/PGL (2). Subsequently, germline mutations in the $S D H B$ and $S D H C$ genes were identified, as well as mutations in the gene encoding for the SDHA subunit (4). Initially, the latter was not associated with the occurrence of PCC/PGL, but with early onset of Leigh syndrome (4). Assembly of the SDH complex requires two factors: SDHAF1 and SDHAF2 $(5,6)$. SDHAF1 mutations are related to infantile leukoencephalopathy, while $S D H F 2$ mutations are involved in the development of PGL but not of PCC $(5,6)$.

$S D H$ genes are tumour-suppressor genes. They are generally affected by point-mutations (missense, nonsense, frameshift and splicing) and transmitted via an autosomal dominant pattern of inheritance, with varying degrees of penetrance. Genotypic alterations more often concern $S D H D$ (7\% of PCC/PGL) and $S D H B$ (5\% of PCC/PGL) genes. Mutations in the $S D H C, S D H A F 2$ and $S D H A$ genes are less frequent (1).

Germline mutations in any of the $S D H x$ genes, as well as hypermethylation of the $S D H C$ promoter region $(7,8)$, result in loss of SDHB protein expression, which is retained in 
wild-type and non-SDH-related tumours (9). Consequently, immunohistochemistry has been proposed for triage genetic testing in order to reduce time and costs. Recent findings indicate that SDHB immunohistochemical status strongly correlates with PCC/PGL clinical outcome, thus emphasising the role of SDHB immunohistochemistry as a prognostic marker (10-12). Loss of both SDHB and SDHA immunoreactivity is evident only in SDHA-mutated tumours, whereas SDHA expression is retained in the context of other $S D H x$ mutations (4). In a retrospective case series, we investigated whether $S D H x$-related tumours can be identified by SDHA/SDHB immunohistochemistry.

\section{Patients and Methods}

Patients with PCC/PGL. Over the past 6 years, 106 patients were diagnosed with PCC/PGL at the Endocrinology Section of the University of Florence, Italy. For the present study, we selected 13 patients with $S D H x$ mutation and 16 with wild-type $S D H x$, randomly chosen within the cohort. Following the protocol approved by our Local Ethical Committee (Prot. N. 2011/0020149), tissue specimens and blood samples were collected for DNA and mRNA analyses, as well as biochemical and morphological assays. All patients gave their informed consent. After surgery, tissues were immediately frozen in liquid nitrogen and stored at $-80^{\circ} \mathrm{C}$.

Genetic analysis. DNA was extracted from the peripheral blood leukocytes of each patient using the NucleoSpin Blood L kit (Macherey-Nagel, Düren, Germany) and analysed for germline mutations of $S D H A$ (all exons), $S D H B$ (all exons), $S D H C$ (all exons), SDHD (all exons), SDHAF1 (all exons), SDHAF2 (all exons), Myc-associated factor $\mathrm{X}(M A X)$ (all exons), transmembrane protein (TMEM) 127 (all exons), von Hippel Lindau (VHL) (all exons), and rearranged during transfection (RET) (exons 5, 8, 10, $11,13,14,15$ and 16). For each gene, coding regions and exonintron boundaries were amplified by polymerase chain reaction (PCR) as previously described (13). PCR products, purified with a commercial PCR purification kit (Qiagen, Milan, Italy), were subjected to $2 \%$ agarose gel electrophoresis with ethidium bromide staining and subsequently sequenced with a genetic analyser (ABI PRISM 310; Applied Biosystems, Milan, Italy).

Tissue homogenates and lysates. Unless specified, all reagents were purchased from Sigma (Sigma-Aldrich, Milan, Italy). Homogenates were prepared as previously described (14). Briefly, dissected tissues (50-150 mg) were finely chopped, re-suspended in a solution containing $120 \mathrm{mM} \mathrm{KCl}, 20 \mathrm{mM}$ HEPES, $2 \mathrm{mM} \mathrm{MgCl}_{2}, 1 \mathrm{mM}$ EGTA, $5 \mathrm{mg} / \mathrm{ml}$ bovine serum albumin, and homogenized in a handheld glass/glass homogenizer. The homogenates were centrifuged at $800 \times \mathrm{g}$ for $10 \mathrm{~min}$ at $4^{\circ} \mathrm{C}$ and the enzyme assays were carried out on the supernatant. For western blot analysis, chopped tissues were lysed in a buffer $(50 \mathrm{mM}$ Tris- $\mathrm{HCl}, \mathrm{pH} 7.5,120 \mathrm{mM} \mathrm{NaCl}, 1 \mathrm{mM}$ EGTA, $6 \mathrm{mM}$ EDTA $15 \mathrm{mM} \mathrm{Na}_{4} \mathrm{P}_{2} \mathrm{O}_{7}, 20 \mathrm{mM} \mathrm{NaF}, 1 \%$ Triton $\mathrm{X}-100$ and protease inhibitor cocktail) homogenized in a hand-held glass/glass homogenizer and kept for $30 \mathrm{~min}$ on ice. Lysates were clarified by centrifugation at $10,000 \times g$ for $15 \mathrm{~min}$ at $4^{\circ} \mathrm{C}$. Supernatants were quantified for protein content (Coomassie Blue reagent; Bio-Rad, Hercules, CA, USA). All procedures were performed on ice or at $4^{\circ} \mathrm{C}$.
SDH activity. Tissue homogenates $(50 \mu \mathrm{g})$ were incubated in a phosphate buffer containing sodium azide, 2,6-dichlorophenolindophenol (DCPIP), sodium succinate, and phenazine methosulfate. Complex II specific activity was assessed by photometry, using a Victor3 1420 Multilabel Counter (Packard Instruments, Perkin-Elmer, Waltham, MA, USA), by measuring the decrease in absorbance due to oxidation of DCPIP at $600 \mathrm{~nm}$ (14).

Western blot. Samples of clarified lysates (30 $\mu \mathrm{g}$ of proteins) were separated by sodium dodecyl sulphate-polyacrylamide gel electrophoresis, and transferred onto polyvinylidene difluoride (Immobilon, Millipore, MA, USA), as previously described (15). Bound antibodies were detected using ECL reagents (Immobilon, Millipore, MA, USA) and analysed with a Biorad ChemiDoc Imaging System for dedicated chemiluminescent image acquisition (Imaging and Analysis Software by Bio-Rad, Quantity-One). The polyclonal anti-SDHB was from Sigma (HPA002868; Sigma-Aldrich, St. Louis, MO, USA), and the monoclonal anti-SDHA from Abcam (clone 2E3GC12FB2AE2; Abcam, Cambridge, UK). The polyclonal antiactin and all the secondary antibodies, namely anti-rabbit, anti-mouse and anti-goat immunoglobulin $\mathrm{G}$ conjugated to horseradish peroxidase, were supplied by Santa Cruz Biotechnology (Santa Cruz, CA, USA).

Immunohistochemistry. Specimens were obtained by surgical resection in all cases and fixed in $10 \%$ formalin before being processed in paraffin. Haematoxylin-eosin stained sections from each specimen were reviewed by two pathologists to confirm the histological diagnosis.

For immunohistochemical analysis, a representative $3-\mu \mathrm{m}$ section for each lesion was selected. All sections were deparaffinised in Bio-Clear (Bio-Optica, MiIan, Italy) and hydrated with series of graded ethanol concentrations to distilled water.

Antigen retrieval was performed by calibrated water bath capable of maintaining the epitope retrieval solution EDTA $\left(\mathrm{pH} \mathrm{9.0)}\right.$ ) at $97^{\circ} \mathrm{C}$ for $20 \mathrm{~min}$. Sections were then allowed to cool to room temperature for $20 \mathrm{~min}$.

In order to block endogenous peroxidase activity, slides were treated with $3.0 \%$ hydrogen peroxidase in phosphate-buffered saline (PBS) for 10 min and, after washing with PBS (Dako Wash Buffer $10 x)$ two or three times, was incubated with rabbit polyclonal antiSDHB (1:800; Sigma-Aldrich, St. Louis, MO, USA) overnight at $4^{\circ} \mathrm{C}$. Serial sections of the same specimen were immunostained with mouse monoclonal anti-SDHA (1:2000; Abcam) for $20 \mathrm{~min}$ at room temperature.

Immunohistochemical analysis was performed using DAKO EnVision $^{\mathrm{TM}}$ FLEX (DAKO, Carpenteria, CA, USA) and 3.3'diaminobenzidine as the chromogen. Sections of PCC were used as positive control for SDHB and SDHA. Negative control was performed by substituting the primary antibody with a non-immune serum at the same concentration. Control sections were treated in parallel with the samples. The sections were lightly counterstained with Mayer's haematoxylin.

In accordance with Gill and co-authors, definite granular cytoplasmic staining was scored as positive and faint cytoplasmic blush as weakly diffuse (16). Cases lacking cytoplasmic staining in the presence of an internal positive control of non-neoplastic cells were classified as negative.

Statistical analysis. Statistical analysis was performed using oneway analysis of variance (ANOVA) followed by the Bonferroni's 
Table I. Succinate dehydrogenase A (SDHA) and SDHB immunohistochemical (IHC) results in a series of SDHx-mutated tumours.

\begin{tabular}{|c|c|c|c|c|c|c|c|}
\hline Site & Gender & Age, years & Gene affected & Mutation & Protein & SDHA IHC & SDHB IHC \\
\hline CBT & $\mathrm{F}$ & 36 & $S D H B$ & c. $572 \mathrm{G}>\mathrm{A}$ & p. Cys191Tyr & Intact & Lost \\
\hline CBT & M & 40 & $S D H B$ & c. $572 \mathrm{G}>\mathrm{A}$ & p. Cys 191Tyr & Intact & Lost \\
\hline $\mathrm{ABD}$ & $\mathrm{F}$ & 55 & $S D H B$ & c. $287-1 \mathrm{G}>\mathrm{C}$ & IVS3-1G>C & Intact & Lost \\
\hline $\mathrm{ABD}$ & $\mathrm{F}$ & 16 & $S D H C$ & c. $126 \mathrm{G}>\mathrm{A}$ & p.Trp42X & Intact & Lost \\
\hline ABD & M & 64 & $S D H D$ & c. $242 \mathrm{C}>\mathrm{T}$ & p.Pro81Leu & Intact & Intact \\
\hline CBT & M & 36 & $S D H D$ & c. $242 \mathrm{C}>\mathrm{T}$ & p.Pro81Leu & Intact & Intact \\
\hline CBT & $\mathrm{F}$ & 61 & $S D H D$ & c. $242 \mathrm{C}>\mathrm{T}$ & p.Pro81Leu & Intact & Lost \\
\hline CBT & $\mathrm{F}$ & 36 & $S D H D$ & c. $242 \mathrm{C}>\mathrm{T}$ & p.Pro81Leu & Intact & Weakly diffuse \\
\hline CBT & $\mathrm{F}$ & 62 & $S D H D$ & c. $317 \mathrm{G}>\mathrm{A}$ & p.Gly 106Asp & Intact & Lost \\
\hline ADR & M & 20 & $S D H D$ & c. $325 \mathrm{C}>\mathrm{T}$ & p.Gln109X & Intact & Lost \\
\hline ABD & M & 51 & $S D H D$ & c. $325 \mathrm{C}>\mathrm{T}$ & p.Gln109X & Intact & Lost \\
\hline $\mathrm{ABD}$ & M & 42 & $S D H D$ & c. $325 \mathrm{C}>\mathrm{T}$ & p.Gln109X & Intact & Lost \\
\hline CBT & $\mathrm{F}$ & 27 & $S D H D$ & c. $170-1 \mathrm{G}>\mathrm{T}$ & IVS2-1G>T & Intact & Lost \\
\hline
\end{tabular}

F: Female; M: male; ADR, adrenal; ABD, intra-abdominal extra-adrenal; CBT, carotid body tumour.

post-test for multiple comparisons. A value of $p<0.05$ was considered significant. Data are reported as means \pm SD of at least three experiments.

\section{Results}

Genetic analysis. Our cohort of 29 patients consisted of 13 $(44.8 \%)$ with PCC, five males and eight females aged between 20 to 80 years (mean $=49.5$ years), and $16(55.2 \%)$ with PGL, six males and 10 females aged between 15 and 72 years (mean $=46.3$ years).

Both wild-type $(\mathrm{n}=16)$ and $S D H x$-mutated tumours $(\mathrm{n}=13)$ were identified. Among the $13 S D H x$-mutated tumours, the $S D H B$ gene was involved in three $(23.1 \%)$ cases (two missense cysteine-to-valine replacement mutations in position 191 and one splicing mutation), the SDHC gene in one case $(7.7 \%$ ) (a non-sense mutation with protein translation interrupted in position 42) and $S D H D$ gene in nine $(69.2 \%)$ cases (five missense mutations, four prolineto-leucine replacements in position 81 and one glycine-toaspartate in position 106, three non-sense mutations with protein translation interrupted in position 109, and one splicing mutation). With regard to anatomical location, the $S D H B$-mutated cases were carotid body $(\mathrm{n}=2)$ and abdominal tumours $(\mathrm{n}=1)$. The $S D H C$-mutated case was an abdominal tumour, whereas the $S D H D$-mutated cases were carotid body $(\mathrm{n}=5)$, abdominal $(\mathrm{n}=3)$ and adrenal $(\mathrm{n}=1)$ tumours. In our series, no tumours harbouring SDHA genetic mutations were identified (Table I).

SDH activity and western blot analysis. All SDHx-mutated PCCs/PGLs exhibited significantly decreased SDH activity, ranging from $60 \%$ to $90 \%$ (Figure 1A). On western blot analysis, levels of SDHA protein expression were similar in all tissue samples (Figure 1B). Enzymatic activity and SDHB
Table II. Succinate dehydrogenase A (SDHA) and SDHB immunohistochemical (IHC) results in a series of wild-type tumours.

\begin{tabular}{lcccc}
\hline Site & Gender & Age, years & SDHA IHC & SDHB IHC \\
\hline ADR & $\mathrm{M}$ & 48 & Intact & Intact \\
ADR & $\mathrm{F}$ & 56 & Intact & Intact \\
ADR & $\mathrm{F}$ & 64 & Intact & Intact \\
ADR & $\mathrm{F}$ & 60 & Intact & Intact \\
ADR & $\mathrm{M}$ & 58 & Intact & Intact \\
ADR & $\mathrm{F}$ & 52 & Intact & Intact \\
ADR & $\mathrm{F}$ & 70 & Intact & Intact \\
ADR & $\mathrm{F}$ & 58 & Intact & Intact \\
ADR & $\mathrm{F}$ & 27 & Intact & Intact \\
ADR & $\mathrm{F}$ & 49 & Intact & Intact \\
ABD & $\mathrm{F}$ & 27 & Intact & Intact \\
ABD & $\mathrm{F}$ & 59 & Intact & Intact \\
ADR & $\mathrm{M}$ & 35 & Weakly diffuse & Intact \\
ADR & $\mathrm{M}$ & 52 & Intact & Intact \\
ADR & $\mathrm{M}$ & 36 & Intact & Intact \\
CBT & $\mathrm{F}$ & 73 & Intact & Intact \\
\hline
\end{tabular}

F: Female; M: male; ADR, Adrenal; ABD, intra-abdominal extraadrenal; CBT, carotid body tumour.

expression levels were significantly reduced in tumours harbouring $S D H x$ mutations (Figure $1 \mathrm{~B}$ and C).

Immunohistochemistry. SDHB immunostaining detected 10/13 (76.9\%) SDHx-mutated PCCs/PGLs: 3/3 SDHBmutated, 1/1 SDHC-mutated and 6/9 SDHD-mutated samples. In three $S D H D$-mutated tumours with the same mutation (p.Pro81Leu), the SDHB staining pattern was positive $(n=2 ; 15.4 \%)$ or weakly diffuse $(n=1 ; 7.7 \%)$ (Table I and III; Figure 2). SDHA protein expression was preserved in all mutated tumours $(n=13 / 13)$ (Table I). 

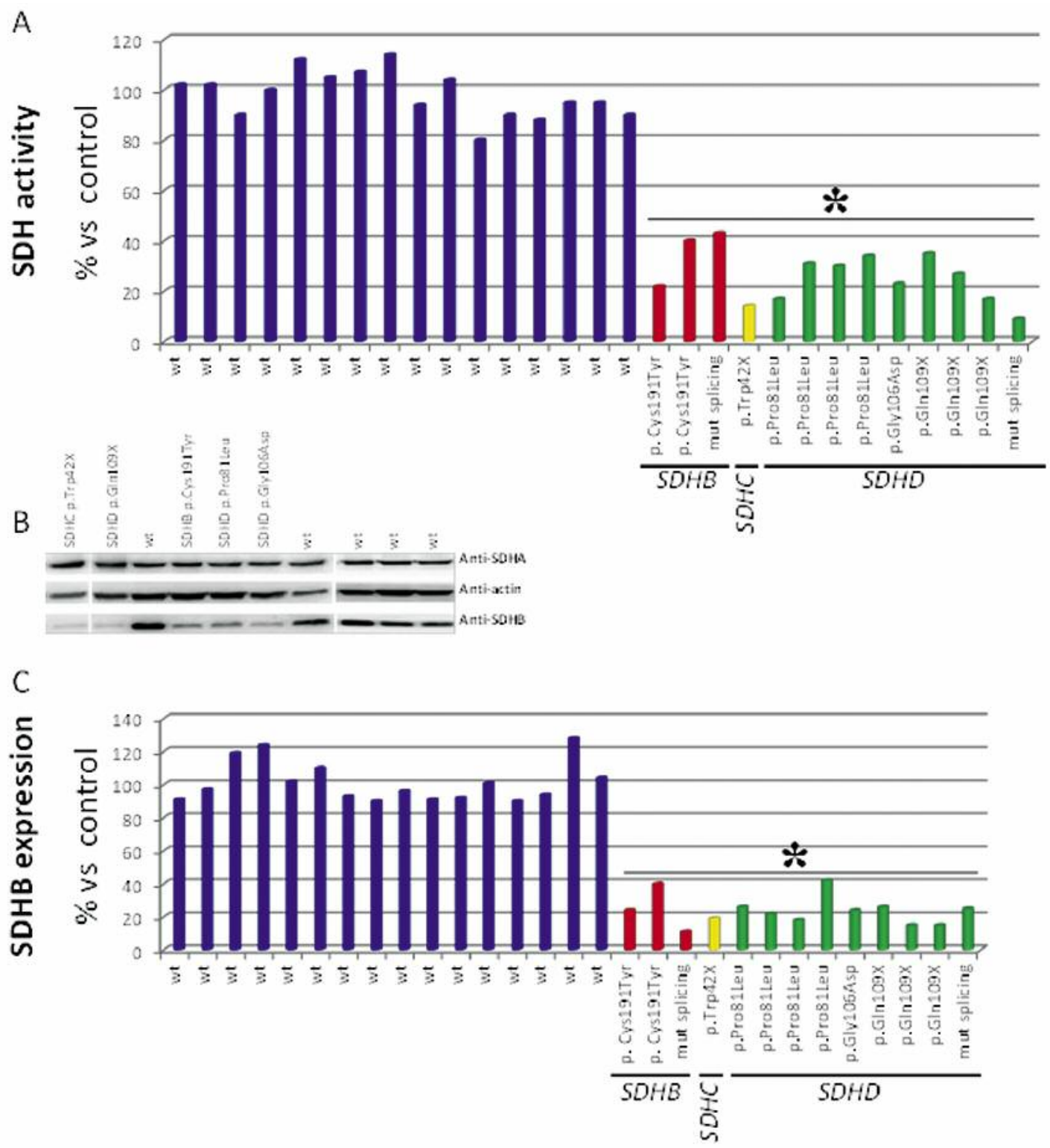

Figure 1. Succinate dehydrogenase (SDH) activity and expression in phaeochromocytomas/paragangliomas. A: The histogram represents SDH activity expressed as the percentage of the activity measured in tissue homogenates. B: Blot shown is representative of samples from patients with mutated and wild-type (wt) SDHx. C: SDHB expression values were normalized to those of actin. Bars are the mean $\pm S . D$. of three independent experiments, $* p<0.05$ compared to control. Enzymatic activity and protein expression were significantly lower in tumours with SDHx mutations than in wild-type tumours.

All 16 wild-type PCCs/PGLs exhibited SDHB immunoreactivity, while SDHA was positive in $15(93.8 \%)$ cases and weakly diffuse in one (6.2\%) (Tables II and III).

Comparison of immunohistochemistry with gene sequencing underlined the high specificity of SDHB staining $(100 \%)$, with $84.6 \%$ sensitivity. Furthermore, positive predictive values reached $100 \%$ and negative predictive values $88.9 \%$.

\section{Discussion}

Ascertaining whether an individual carries a genetic predisposition for developing PCC/PGL provides important clinical information on the patient's risk of presenting malignant or multifocal lesions, as well as other benign and malignant neoplasms (17-19). The literature provides much evidence to suggest that immunohistochemical staining for 

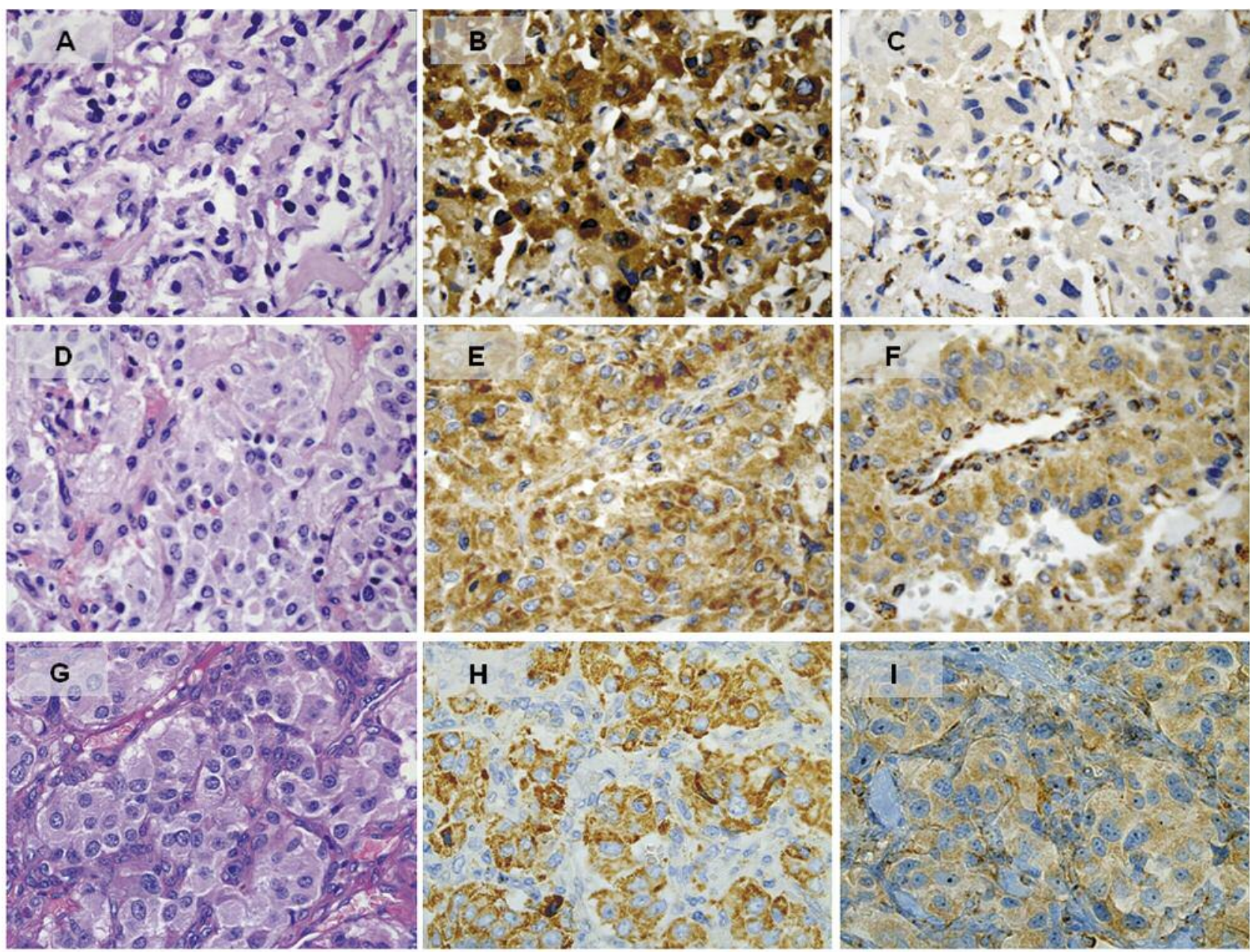

Figure 2. SDHD-mutated (p.Gln109X) extra-adrenal paraganglioma $(P G L)(A$; haematoxylin-eosin, $x 40)$ immunoreactive for SDHA (B) and negative for SDHB; note that the normal cells of the intratumoural fibrovascular network retain SDHB positivity (C). SDHD-mutated (p.Pro81Leu) extraadrenal PGL (D; haematoxylin-eosin, $\times 40)$ positive for SDHA $(E)$ and negative for SDHB $(F)$. Carotid body tumour $(G$; haematoxylin-eosin, $x 40)$ harbouring SDHD mutation (p.Pro81Leu) with positive staining for SDHA (H) and weak non-specific cytoplasmic staining for SDHB (I).

Table III. Comparison of immunohistochemistry with gene sequencing showed succinate dehydrogenase B staining to be highly specific (100\%), with $84.6 \%$ sensitivity. Positive and negative predictive values were $100 \%$ and $88.9 \%$, respectively.

\begin{tabular}{|c|c|c|c|c|c|c|}
\hline & \multicolumn{3}{|c|}{ SDHA, n (\%) } & \multicolumn{3}{|c|}{ SDHB, n (\%) } \\
\hline & Intact & Weakly diffuse & Lost & Intact & Weakly diffuse & Lost \\
\hline Wild-type & $15(93.8 \%)$ & $1(6.2 \%)$ & 0 & $16(100 \%)$ & 0 & 0 \\
\hline$S D H x$-mutated & $13(100 \%)$ & 0 & 0 & $2(15.4 \%)$ & $1(7.7 \%)$ & $10(76.9 \%)$ \\
\hline
\end{tabular}

SDHB can reliably identify patients with $S D H B, S D H C$ and $S D H D$ gene mutations $(9,16)$, regardless of the underlying type of mutation (missense, nonsense, splicing, or frameshift). Consequently, immunohistochemistry has been proposed as a screening/triaging test $(9,16,20)$. Because of the rarity of sporadic SDHx mutations, loss of SDHB immunoreactivity suggests the presence of a germline mutation in the SDH complex and thus indicates the patient for appropriate genetic testing. On the other hand, in $85 \%$ of the PCC/PGL cases in which SDHB expression is expected 
to be maintained, immunohistochemistry can exclude the need for genetic testing. This approach may be highly beneficial as well as economically sustainable (20).

The results of our study focus attention on the possible pitfalls in identifying patients with $S D H x$ germline mutations by means of immunohistochemistry, particularly in the presence of $S D H D$ gene mutations. Reproducibility in the interpretation of immunohistochemical results is crucial if this technique is to be used as a tool for genetic screening. We adopted the three-category grading system proposed by Gill and collaborators for evaluation of SDHB immunostaining (16). This method seems to improve interobserver concordance when compared to the two-category grading system suggested by van Nederveen and collaborators, which distinguishes between SDHB-positive and SDHB-negative tumours (21). In a study of 43 PCC/PGL cases, including wild-type $(\mathrm{n}=30)$ and RET $(\mathrm{n}=3), \operatorname{VHL}(\mathrm{n}=4), \operatorname{SDHB}(\mathrm{n}=3)$ and $\operatorname{SDHD}(\mathrm{n}=3)$ mutation-associated tumours, SDHB immunostaining identified only the $S D H x$-mutated tumours. SDHB was positive in the wild-type, RET-mutated tumours and in two out of the four $V H L$-mutated tumours. The two other cases associated with VHL mutations, showing weakly diffuse cytoplasmic blush, were considered negative. However, when the criteria put forward by Gill and co-workers were applied and the granular staining pattern considered, the two $V H L$-mutated cases were deemed as SDHB-positive (20). It is well-known that $V H L$ mutated PCCs/PGLs may display decreased SDHB expression, thus justifying the weakly diffuse staining at immunohistochemistry $(10,16,22)$. Therefore if immunohistochemistry is negative, but no SDHx mutation is detected, VHL testing should be recommended. On the contrary, if immunohistochemistry is positive with no mutation in other candidate genes (i.e. VHL, MEN2), then SDHD mutation should be considered if history is suggestive.

In our series, false-negative cases harboured the same mutation in the $S D H D$ gene (c.242 C $>\mathrm{T})$. Immunostaining was positive in two cases and weakly diffuse in one. These data are in line with previous studies $(10,16,21)$. Papathomas and co-authors investigated interobserver variability among seven expert endocrine pathologists using a web-based virtual microscopy approach in a large multicentre PCC/PGL cohort $(\mathrm{n}=351)$ and identified two $S D H D$-mutated extra-adrenal PGL which five observers considered SDHB-positive (10). However, no correlation was found between a weakly diffuse staining pattern and $S D H D$ mutation. It has been proposed that $S D H D$ gene mutations can induce misfolding of the subunits of the SDH complex, with loss of enzymatic activity, while exhibiting an abnormal pattern of immunoreactivity (21). Owing to the possibility of positive or weakly diffuse SDHB immunoreactivity in tumours harbouring SDHD mutations, $S D H D$ staining may be a complementary tool to identify patients with $S D H D$ mutation (23). In the current study, we obtained a positive predictive value of $100 \%$ and a negative predictive value of $88.9 \%$ for the presence of SDH mutations, employing the same commercially available antibody to SDHB (polyclonal anti-rabbit, HPA002868) used by van Nederveen et $a l$., although at a different concentration (1:500 vs. 1:800) (9). Similar results were also reported using the 21A11 mouse monoclonal antibody to SDHB (16).

In order to correctly evaluate immunohistochemical results, SDHB immunohistochemistry must be performed following well-defined, standardized protocols and in laboratories subject to internal and external quality control. Good practice requires inclusion of internal positive controls (i.e. sustentacular cells and endothelia). Moreover, SDHB and SDHA immunohistochemistry is not always an all-ornone phenomenon and the staining pattern may be heterogeneous. In these cases, $S D H x$ genetic testing is recommended (10).

In previous studies, the percentage of SDHB-negative PCCs/PGLs without SDHx mutations ranged between $5.6 \%$ (2/36) (16) and $15.7 \%$ (3/19) (21). Failure of genetic analysis to identify $S D H x$ gene mutations, which may be attributable to large-scale deletions or implicate non-transcribed regions, introns or promoters, and epigenetic modifications have been given as explanations for these false-positive results (21). Loss of SDHB immunohistochemical expression has been observed in gastrointestinal stromal tumours as part of the Carney-Stratakis syndrome and the Carney triad (24-26). Recently, two groups working independently reported an aberrant DNA methylation pattern at the SDHC gene locus (SDHC epimutation) in tumours of patients with Carney triad, suggesting its epigenetic inactivation with functional impairment of the $S D H x$ complex as a plausible alternative mechanism of tumorigenesis in Carney triad (7, 27). Based on these observations, in patients affected by gastrointestinal stromal tumours showing loss of SDHB expression, close follow-up is recommended to monitor any possible development of PGL or chondromas of the lung $(24,25)$. If $S D H x$ genetics does not reveal any mutation in SDHBimmunonegative tumours, $S D H C$ promoter methylation or VHL/NF1 testing can be applied (10).

Our study has a few limitations, including a small sample size. However, in line with previous reports, our study confirms that SDHA protein immunohistochemical expression is maintained in tumours with $S D H B, S D H C$ and $S D H D$ gene mutations. We also observed a wild-type tumour which was SDHA-negative. Nevertheless, this result should not be considered a false-positive because SDHB expression was preserved.

In conclusion, SDHB immunostaining is a useful tool in identifying PCC/PGL associated with mutations of the SDHx genes. Rigorous scoring guidelines are mandatory in clinical reporting if standards of reproducibility are to be improved. One controversial issue is the interpretation of weakly 
diffuse SDHB immunostaining, from both the technical and diagnostic perspective. This category is most frequently associated with $S D H D$ mutations. A better understanding of the genetic basis of tumorigenesis of PCCs/PGLs may explain unexpected immunohistochemical results.

\section{References}

1 Welander J, Söderkvist P and Gimm O: Genetics and clinical characteristics of hereditary pheochromocytomas and paragangliomas. Endocr Relat Cancer 18: 253-276, 2011.

2 Pillai S, Gopalan V, Smith RA and Lam AK: Updates on the genetics and the clinical impacts on phaeochromocytoma and paraganglioma in the new era. Crit Rev Oncol Hematol 100: 190-208, 2016.

3 Baysal BE, Ferrell RE, Willett-Brozick JE, Lawrence EC, Myssiorek D, Bosch A, van der Mey A, Taschner PE, Rubinstein WS, Myers EN, Richard CW 3rd,Cornelisse CJ, Devilee P and Devlin B: Mutations in $S D H D$, a mitochondrial complex II gene, in hereditary paraganglioma. Science 287: 848-851, 2000.

4 Korpershoek E, Favier J, Gaal J, Burnichon N, van Gessel B, Oudijk L, Badoual C, Gadessaud N, Venisse A, Bayley JP, van Dooren MF, de Herder WW,Tissier F, Plouin PF, van Nederveen FH, Dinjens WN, Gimenez-Roqueplo AP and de Krijger RR: SDHA immunohistochemistry detects germline SDHA gene mutations in apparently sporadic paragangliomas and pheochromocytomas. J Clin Endocrinol Metab 96: E1472-1476, 2011.

5 Ghezzi D, Goffrini P, Uziel G, Horvath R, Klopstock T, Lochmüller H, D'Adamo P, Gasparini P, Strom TM, Prokisch H, Invernizzi F, Ferrero I and Zeviani M: SDHAF1, encoding a LYR complex-II specific assembly factor, is mutated in SDH-defective infantile leukoencephalopathy. Nat Genet 41: 654-656, 2009.

6 Hao HX, Khalimonchuk O, Schraders M, Dephoure N, Bayley JP, Kunst H, Devilee P, Cremers CW, Schiffman JD, Bentz BG, Gygi SP, Winge DR, Kremer H and Rutter J: SDH5, a gene required for flavination of succinate dehydrogenase, is mutated in paraganglioma. Science 325: 1139-1142, 2009.

7 Haller F, Moskalev EA, Faucz FR, Barthelmeß S, Wiemann S, Bieg M, Assie G, Bertherat J, Schaefer IM, Otto C, Rattenberry E, Maher ER, Ströbel P, Werner M, Carney JA, Hartmann A, Stratakis CA and Agaimy A: Aberrant DNA hypermethylation of SDHC: a novel mechanism of tumor development in Carney triad. Endocr Relat Cancer 21: 567-577, 2014.

8 Richter S, Klink B, Nacke B, de Cubas AA, Mangelis A, Rapizzi E, Meinhardt M, Skondra C, Mannelli M, Robledo M, Menschikowski M and Eisenhofer G: Epigenetic mutation of the succinate dehydrogenase $\mathrm{C}$ promoter in a patient with two paragangliomas. J Clin Endocrinol Metab 101: 359-363, 2016.

9 Van Nederveen FH, Gaal J, Favier J, Korpershoek E, Oldenburg RA, De Bruyn EM, Sleddens HF, Derkx P, Rivière J, Dannenberg H, Petri BJ, Komminoth P, Pacak K, Hop WC, Pollard PJ, Mannelli M, Bayley JP, Perren A, Niemann S, Verhofstad AA, de Bruïne AP, Maher ER, Tissier F, Méatchi T, Badoual C, Bertherat J, Amar L, Alataki D, Van Marck E, Ferau F, François J, de Herder WW, Peeters MP, van Linge A, Lenders JW, Gimenez-Roqueplo AP, de Krijger RR and Dinjens WN: An immunohhistochemical procedure to detect patients with paraganglioma and pheochromocytoma with germline $S D H B, S D H C$, or $S D H D$ gene mutations: a retrospective and prospective analysis. Lancet Oncol 10: 764-771, 2009.
10 Papathomas TG, Oudijk L, Persu A, Gill AJ, van Nederveen F, Tischler AS, Tissier F, Volante M, Matias-Guiu X, Smid M, Favier J, Rapizzi E, Libe R, Currás-Freixes M, Aydin S, Huynh T, Lichtenauer U, van Berkel A, Canu L, Domingues R, CliftonBligh RJ, Bialas M, Vikkula M, Baretton G, Papotti M, Nesi G, Badoual C, Pacak K, Eisenhofer G, Timmers HJ, Beuschlein F, Bertherat J, Mannelli M, Robledo M, Gimenez-Roqueplo AP, Dinjens WN, Korpershoek E and de Krijger RR: SDHB/SDHA immunohistochemistry in pheochromocytomas and paragangliomas: a multicenter interobserver variation analysis using virtual microscopy: a Multinational Study of the European Network for the Study of Adrenal Tumors (ENS@T). Mod Pathol 28: 807$821,2015$.

11 Kimura N, Takekoshi K, Horii A, Morimoto R, Imai T, Oki Y, Saito T, Midorikawa S, Arao T, Sugisawa C, Yamada M, Otuka Y, Kurihara I, Sugano K, Nakane M, Fukuuchi A, Kitamoto T, Saito J, Nishikawa T and Naruse M: Clinicopathological study of $S D H B$ mutation-related pheochromocytoma and sympathetic paraganglioma. Endocr Relat Cancer 21: L13-16, 2014.

12 Blank A, Schmitt AM, Korpershoek E, van Nederveen F, Rudolph T, Weber N, Strebel RT, de Krijger R, Komminoth P and Perren A: SDHB loss predicts malignancy in pheochromocytomas/sympathethic paragangliomas, but not through hypoxia signalling. Endocr Relat Cancer 17: 919-928, 2010.

13 Astuti D, Latif F, Dallol A, Dahia PL, Douglas F, George E, Sköldberg F, Husebye ES, Eng C and Maher ER: Gene mutations in the succinate dehydrogenase subunit SDHB cause susceptibility to familial pheochromocytoma and to familial paraganglioma. Am J Hum Genet 69: 49-54, 2001. Erratum in: Am J Hum Genet 70: 565, 2002.

14 Rapizzi E, Ercolino T, Canu L, Giaché V, Francalanci M, Pratesi $\mathrm{C}$, Valeri A and Mannelli M: Mitochondrial function and content in pheochromocytoma/paraganglioma of succinate dehydrogenase mutation carriers. Endocr Relat Cancer 19: 261-269, 2012.

15 Rapizzi E, Taddei ML, Fiaschi T, Donati C, Bruni P and Chiarugi P: Sphingosine 1-phosphate increases glucose uptake through transactivation of insulin receptor. Cell Mol Life Sci 66: 3207-3218, 2009.

16 Gill AJ, Benn DE, Chou A, Clarkson A, Muljono A, MeyerRochow GY, Richardson AL, Sidhu SB, Robinson BG and Clifton-Bligh RJ: Immunohistochemistry for SDHB triages genetic testing of $S D H B, S D H C$, and $S D H D$ in paraganglioma-pheochromocytoma syndrome. Hum Pathol 41: 805-814, 2010.

17 Amar L, Bertherat J, Baudin E, Ajzenberg C, Bressac-de Paillerets B, Chabre O, Chamontin B, Delemer B, Giraud S, Murat A, Niccoli-Sire P, Richard S, Rohmer V, Sadoul JL, Strompf L, Schlumberger M, Bertagna X, Plouin PF, Jeunemaitre $X$ and Gimenez-Roqueplo AP: Genetic testing in pheochromocytoma or functional paraganglioma. J Clin Oncol 23: 8812-8818, 2005.

18 Timmers HJ, Kozupa A, Eisenhofer G, Raygada M, Adams KT, Solis D, Lenders JW and Pacak K: Clinical presentations, biochemical phenotypes, and genotype-phenotype correlations in patients with succinate dehydrogenase subunit B-associated pheochromocytomas and paragangliomas. J Clin Endocrinol Metab 92: 779-786, 2007.

19 Fishbein L and Nathanson KL: Pheochromocytoma and paraganglioma: understanding the complexities of the genetic background. Cancer Genet 205: 1-11, 2012. 
20 Pai R, Manipadam MT, Singh P, Ebenazer A, Samuel P and Rajaratnam S: Usefulness of succinate deydrogenase B (SDHB) immunohistochemistry in guiding mutational screenig among patients with pheochromocytoma-paraganglioma syndromes. APMIS 122: 1130-1135, 2014.

21 Castelblanco E, Santacana M, Valls J, de Cubas A, Cascón A, Robledo $\mathrm{M}$ and Matias-Guiu X: Usefulness of negative and weak-diffuse pattern of SDHB immunostainig in assessment of SDH mutations in paragangliomas and pheochromocytomas. Endocr Pathol 24: 199-205, 2013.

22 Dahia PL and Familial Pheochromocytoma Consortium: Transcription association of $V H L$ and SDH mutations link hypoxia and oxidoreductase signals in pheochromocytomas. Ann NY Acad Sci 1073: 208-220, 2006.

23 Menara M, Oudijk L, Badoual C, Bertherat J, Lepoutre-Lussey C, Amar L, Iturrioz X, Sibony M, Zinzindohoué F, de Krijger R, Gimenez-Roqueplo AP and Favier J: SDHD immunohistochemistry: a new tool to validate $S D H x$ mutations in pheochromocytoma/paraganglioma. J Clin Endocrinol Metab 100: E287-291, 2015.

24 Gill AJ, Chou A, Vilain R, Clarkson A, Lui M, Jin R, Tobias V, Samra J, Goldstein D, Smith C, Sioson L, Parker N, Smith RC, Sywak M, Sidhu SB, Wyatt JM, Robinson BG, Eckstein RP, Benn DE and Clifton-Bligh RJ: Immunohistochemistry for SDHB divides gastrointestinal stromal tumors (GISTs) into two distinct types. Am J Surg Pathol 34: 636-644, 2010.
25 Gaal J, Stratakis CA, Carney JA, Ball ER, Korpershoek E, Lodish MB, Levy I, Xekouki P, van Nederveen FH, den Bakker MA, O'Sullivan M, Dinjens WN and de Krijger RR: SDHB immunohistochemistry: a useful tool in the diagnosis of CarneyStratakis and Carney triad gastrointestinal stromal tumors. Mod Pathol 24: 147-151, 2011.

26 Rubin BP and Heinrich MC: Genotyping and immunohistochemistry of gastrointestinal stromal tumors: An update. Semin Diagn Pathol 32: 392-399, 2015.

27 Killian JK, Miettinen M, Walker RL, Wang Y, Zhu YJ, Waterfall JJ, Noyes N, Retnakumar P, Yang Z, Smith WI Jr, Killian MS, Lau CC, Pineda M, Walling J, Stevenson H, Smith C, Wang Z, Lasota J, Kim SY, Boikos SA, Helman LJ and Meltzer PS: Recurrent epimutation of $S D H C$ in gastrointestinal stromal tumors. Sci Transl Med 6: 268ra177, 2014.
Received December 6, 2016

Revised January 19, 2017

Accepted January 24, 2017 